\title{
WORK UNDER URGENCY AND EMERGENCY AND ITS RELATION WITH THE HEALTH OF NURSING PROFESSIONALS ${ }^{1}$
}

Daiane Dal Pai

Liana Lautert ${ }^{3}$

Dal Pai D, Lautert L. Work under urgency and emergency and its relation with the health of nursing professionals. Rev Latino-am Enfermagem 2008 maio-junho; 16(3):439-44.

The study aimed at understanding work under urgent and emergency conditions and its connection with the health of nursing professionals, who work at an urgency and emergency state service. Descriptive qualitative case study carried out at a state service in Porto Alegre, RS. The collection of data included the analysis of documents from the Institution, the observation of the work dynamics, and the performance of semi-structured interviews with the nursing professionals. The data were submitted to content analysis. One could understand that the health of the nursing professionals is constituted from a working dynamics which is sometimes harmful because it results from an organizational context that carries marks of a state health system with many gaps, however, that allows the meaning of work to be an essential element for the ability to keep the balance and not getting sick in view of the work demands.

DESCRIPTORS: occupational health; working conditions; job satisfaction; health facilities; health manpower; emergency nursing; working environment

\section{EL TRABAJO EN URGENCIA Y EMERGENCIA Y SU RELACIÓN CON LA SALUD DE LOS PROFESIONALES DE ENFERMERÍA}

El estudio tuvo por objetivo comprender el trabajo en urgencia y emergencia y su relación con la salud de los profesionales de enfermería, que trabajan en un servicio público de emergencia. Se trata de un estudio de caso, cualitativo descriptivo, realizado en un servicio público de Porto Alegre - RS. La recolección de los datos incluyó el análisis de documentos de la institución, la observación en la dinámica del servicio y entrevistas semi-estructuradas con profesionales de enfermería. Los datos fueron procesados a través del método de análisis de contenido. Fue posible comprender que la salud de las profesionales de enfermería se constituye a partir de una dinámica de trabajo, que a veces daña la salud, producto de un contexto organizacional marcado por un sistema público de salud con muchos vacíos, sin embargo permite que el trabajo sea realizado como elemento fundamental, manteniendo así el equilibrio y no permitiendo la enfermedad frente a las exigencias laborales.

DESCRIPTORES: salud laboral; condiciones de trabajo; satisfacción en el trabajo; instituciones de salud; recursos humanos en salud; enfermería de urgencia; ambiente de trabajo

\section{O TRABALHO EM URGÊNCIA E EMERGÊNCIA E A RELAÇÃO COM A SAÚDE DAS PROFISSIONAIS DE ENFERMAGEM}

O estudo objetivou compreender o trabalho em urgência e emergência na sua relação com a saúde das profissionais de enfermagem, atuantes em um serviço público de pronto-socorro. Trata-se de estudo de caso, qualitativo descritivo, realizado em um serviço público de Porto Alegre, RS. A coleta dos dados incluiu a análise de documentos da Instituição, a observação da dinâmica do serviço e a realização de entrevistas semiestruturadas com as profissionais de enfermagem. Os dados foram submetidos ao método de análise de conteúdo. Pôde-se compreender que a saúde das trabalhadoras é constituída a partir de dinâmica de trabalho, por vezes danosa, resultante de contexto organizacional que carrega marcas de sistema público de saúde com muitas lacunas, mas permitindo que o sentido do trabalho atue como elemento fundamental para a capacidade de se manter o equilíbrio e não adoecer diante das exigências do trabalho.

DESCRITORES: saúde do trabalhador; condições de trabalho; satisfação no emprego; instituições de saúde; recursos humanos em saúde; enfermagem de urgência; ambiente de trabalho

${ }^{1}$ Extracted from Master's Thesis; ${ }^{2}$ M.Sc. in Nursing, Faculty, Centro Universitário Metodista Ipa, Brazil, e-mail: daiadalpai@yahoo.com.br; ${ }^{3}$ Ph.D. in Psychology, Faculty, Rio Grande do Sul Federal University, Brazil, e-mail: lila@enf.ufrgs.br 


\section{INTRODUCTION}

$\boldsymbol{U}_{\text {rgency and emergency public services }}{ }^{*}$ have been characterized by overpopulation, accelerated pace and overload of work for health professionals. These aspects, among many others, are objectively and subjectively implied on the way work dynamics occur in this space and how human beings cope with it. With this in mind, we aimed at studying the connection of this work with the health of nursing professionals, believing that work is never neutral regarding health: it favors either health, or getting sick ${ }^{(1)}$.

The present investigation is linked with the Post Graduation Program of the Nursing School at the Federal University of Rio Grande do Sul, and the purpose was to understand urgency and emergency work, in its relation with the health of nursing professionals working in an emergency public service. The theme of this research came from the work experience in different emergency and urgency public services, associated with reflections on the social reality that has defined the organization of health services and the human relations established in this space. With this starting point, the present study observed the aspects related with the context in which the work dynamics of an urgency and emergency public service is built to question how these professionals keep their health balanced in face of the demands of the job.

In the present study, we understand the health-getting sick relationship as a social process, since the biological and psychological nexus is the expression of a certain historical process that is made concrete in the human body ${ }^{(2)}$. Work is taken as a key element to understand determiners of workers' health.

The theory that guided the study assumes work in health as part of the service industry, characterized by a non-material production that is completed by the action of its performance and whose product cannot be dissociated from the process. Work in health is determined by the socialhistorical process and results from the influence of science regarding the process of health-getting sick, of the available technological resources, the way of production, and the social demands regarding health among others ${ }^{(3)}$.
It is observed that work in health, despite all technological advances, has not demonstrated economy in the workforce. It is essentially supported by intensive labor, with unequal mastering levels by agents on the work process ${ }^{(4-5)}$.

With the characterization of work in health, we refer to the study of the psychodynamics of work by Cristhophe Dejours ${ }^{(6)}$ to search for elements to understand the health-work relation from the forms of organization of work, and the experience of workers regarding them. According to this analysis, to assess work in its relation with health, demands that you have access to the sense workers give to this situation.

In this sense, thinking about work organization requires considering the variable distance between the organization prescribed for work and its real organization. The balance (or health) depends on this distance that enables or hinders mobilization of creativity to intervene on work demands in favor of one's own satisfaction ${ }^{(6)}$.

Disregarding workers knowledge and denying their competence imposing rules as if they were the only ways to perform a job is a pretension that could be harmful for workers if there were no bonds of cooperation created by the collectiveness. This, in turn, goes against prescriptions, breaking work rules to answer the every day demands of work ${ }^{(7-8)}$.

Thus, the same work that produces suffering can also be a source of fulfillment, found in the recognition, since artful intelligence needs, in addition to individual requirements of workers, social validation that is expressed in the recognition of the usefulness of one's work, and the recognition of one's skills by their peers (collective or belonging community) ${ }^{(8-9)}$

\section{METHODOLOGY}

Descriptive study using Case Study as a methodological support to approach particularities and complexities of a particular case aiming at understanding circumstances in which certain phenomenon occur ${ }^{(10)}$. Data collection was performed from July 2005 to January 2006 in a public hospital of Porto Alegre - RS.

Some documents and records were subsidizes to understand the organizational context in which nursing activities were inserted into. Observation, as

* Differentiation between an urgency and emergency case is performed by the level of severity of the disease, life-threatening or the possibility of irreversible damage. However, the term "urgency and emergency" is adopted as a single area of care, according to the use of the term by the Ministry of Health 
an investigation method was chosen to learn interactions between people, and their interaction with the environment in real situations, in addition to giving sense to what is said ${ }^{(11)}$.

Additionally to the non-participant observation, performed in 14 periods of two hours recorded in field diaries, semi-structured interviews were used to describe the characteristics of urgency and emergency work, as well as the sense given by workers to experiences in this place. Interviews were recorded and transcribed in full.

Regarding selection of participants, we have made sure that the suitable sample resulted from the identification and use of participants that could best give information according to the demands of the study ${ }^{(11)}$. Thus, we have opted for intentional choice of the sample, made by 12 nursing professionals: nurses, nursing technicians, and nursing assistants.

Ethical prerogatives were met with the use of the Informed Written Consent and Responsibility Term by Data Use. Confidentiality was assured and interviews were authorized to be recorded, explaining all participants they could stop; ask questions, or criticize at any time. The research project was assessed and approved by the Ethical Research Committee of the Institution where data collection was performed.

Information for the three data collection (document analysis, observation and interview) were gathered and assessed based on the set of methodological instruments of the Content Analysis ${ }^{(12)}$. First, the pre-analysis enabled to have ideas on all information collected; this was performed through pre-reading material. Theoretical reference of the research based selection of important information, paying attention to exhaustiveness, representativeness, and homogeneity of data.

After this, material was organized as of the main themes, coding hard data in extracts that reached a representation of the content or the expression, forming record unities. These unities were gathered in sense categories leading to interpretation sets called: organizational context of the service, work dynamics, and sense of work. Thus, hard data were meaningful for the discussion of the health-work relation.

As of the analysis of data, a set of interpretation texts was designed to answer the objectives of the study. To make the presentation of results easier, the extracts of interviews were classified with letter " $E$ " and those from observations with letter "O", chosen to exemplify and give meaning to the discussion.

\section{PRESENTATION AND DISCUSSION OF RESULTS}

Marks of the every day work in emergency and urgency

The service studied is inserted in an organizational context where issues regarding the current picture of the Brazilian health is implied, the marks define not only institutional rules but also the dynamics of work and the relations built in it.

To understand the nursing work dynamics, we have found care actions that depended on time, unpredictability of the demand and had no routine. In addition to the demand for punctuality and regularity, there is pressure of the frantic rhythm, and the performance of activities that are related with high work demand and the race to save lives ${ }^{(5,13)}$.

[...] it is a very dynamic job, you work taking care, and looking backwards because the entrance door is always open [...] everything occurs at the same time (E-12).

$[\ldots]$ there is no routine in the job, $[\ldots]$ each case is one case, each day is one day, each shift is different, there are shifts sometimes that are calm, some shifts seem to be calm and then turn into chaos! (E-6).

$[. .$.$] that door opens at any time, and we run to answer (E-7).$

The need to speed care was clearly detected both in field observations and interviews, and it was the main purpose of actions developed by nursing in the service studied. This, at times, was a triggering factor of interpersonal conflicts, since taking long in care contributed to overpopulation of the service, as well as increase in work.

Additionally, overpopulation demanded that workers chose, many times, who to care for, letting patients unattended. These situations were identified as potential for suffering at the work place ${ }^{(14)}$, since they made them feel guilty for not doing what is best, leading to personal conflicts, because they considered that the behavior adopted lacked ethics and social commitment.

[Nurse talking to a nursing technician about the emergency room] 'Yesterday there was no room for any stretcher, it was lucky that a guy died because we did not have any more breathers on the hospital' (O-4). 
Conflicts were even more present on nursing work to inform users that were considered "nonurgent" that the service should only be sought for emergencies and urgencies. This has been a very painful task for professionals, because they see their action as not solving, since they do not have a place to refer these people to. From this limitation, suffering arises because their actions have no sense.

[...] ]every time you talk about primary health care, they shrink, everything changes, the energy changes, because then, a table tennis game starts [...] they have been to several primary care unities and you have nothing to say to them, and you have to make them understand. Can you see the dilemma we live in? (E-2).

Additionally, lack in human and material resources was also identified as a poor working condition. However, the worker was so fascinated by high technology in health that she could not reflect on the need for basic resources that are essential to her action and that her feeling of helplessness may also be associated with that ${ }^{(13)}$.

Still regarding means of work, we have observed that behavior of nursing workers is influenced by the position nursing occupies on the division of hospital work. However, in the urgency and emergency work, this division is softened by the need to work intellectually with the risk of death.

This characteristic enables nursing to work in the work conception, making it possible to control the organization of work, which could also be seen in the relationship of nursing with medical residents and interns. In this relation, familiarity of nursing professionals with the world of work gives them more power and thus, gives space for fulfilling desires and needs of workers.

Sometimes we are even a bit arrogant because you get all the tricks, the routine, how to proceed, you know how to take care of patients and sometimes this does not happen. And then we are pressured by residents [...] (E-7).

Another characteristic of the study is the presence of collective agreements that encircle paths to the work, making it possible to meet the needs of these workers. It is in this movement of attitudes and behaviors that professionals have found some breaches for collective and individual fulfillment at work $^{(15)}$.

[Nursing assistants talking] 'Here we are employees and time is the boss, you have to organize yourself, otherwise you suffer the consequences!' (O-2).

On the diversity of factors that mark the routine of nursing workers, it is the aspect that contributes to the protection against suffering at work and, more than that, it is a decisive aspect in the relation that urgency and emergency work established with the health of nursing workers. It is about the sense of work that is an essential element to maintain balance and not getting sick.

The sense of work to the health of workers

Looking at the routine of nursing work in urgency and emergency enabled to see, that even with the difficulties of every day life, the benefit of work for the health is in the symbolic value of action. That is, it is in the moral attribute of the activity.

Thus, the sense of work is what defines the relationship it has with the health of workers, since work is the center of balance in people, and we look for an useful ethical occupation in it, since the sense of work is what offers balance, if it is morally right, and if makes them fell efficient ${ }^{(16-17)}$. On this perspective, the relevance of professional performance is, especially, in the moral valuation of work, and in the pleasure of feeling useful. This value, in the context studied, is attributed to the purpose of the work, which is understood by participants as saving lives.

[...] that is exactly what is good, working at a critical moment, that is critical and crucial, it is that thing of life and death. You get a patient that is severe and after a while the patient is talking, it is gratifying for us! (E-7).

I think the work at emergency is very rich, $[\ldots]$ it is a great contribution to really keep the patient, it is to save and bring the patient back to a life that is extinguishing [...]life is leaving, and we have to bring it back right at that time it is leaving $[\ldots](E-12)$.

The power of saving lives is a self-esteem factor for nursing workers, which integrates human beings to groups with certain social rights ${ }^{(8)}$. Regarding these rights, working "saving lives" is an occupation that brings social rewards, gratitude, and admiration to these professionals.

Skills that make it possible to bring back life are prerogatives that give power to workers of the service studied; they are seen as heroes in the challenge of saving. When they realized they have this gift, the participants of this survey demonstrated pride in what they did.

[...] you see the patient arriving feeling so bad and then leaving thanking you [...] Our service is very rewarding, I get very touched (E-11). 
[...] this type of work is a great source of fulfillment, a source of joy [...] I am very proud of working here. I have seen so many things here! (E-2).

The participants were also proud of the importance of urgency and emergency in the relationship with the other sectors of the hospital. For them, the value given to skills on the nursing work can be used in the privilege of working in the sector that "saves first".

Emergency is the airway of hospitals, it is where people die first, in fact, and it is where you are saved first! [...] There is no use having a well equipped ICU if things do not go well at Emergency. And this job of making things go well is our reality! $(E-12)$.

[...] we have the door, we have to know and be well selected! (E-11).

With this in mind, we have noticed that participants express the preference in working at emergency and urgency sector because of the power to fight death, the skills, and specific knowledge needed to work in this sector, among others.

Professionals working in urgency and emergency services feel they are privileged because they have and practice skills of individual initiative, the ability to make quick decisions, and technical mastering. Likewise, in the context studied, specific skills to perform the work were expressed as demands that determine professional self-valuation of nursing workers $^{(5)}$.

[...] emergency nurses must be creative and they have to work under pressure and stress, they have to know who to deal with all this, [...] they must to have adaptation profile, you have to adjust to the most diverse situations (E-6).

Thus, "what you have to be...you have to know...you have to do" are needs mentioned with pride, since recognition to work ability is a self-esteem factor to these professionals.

By the speech we can infer that reward expected by individuals from work is mainly in the recognition, which is not only an ornament in the speech of workers, but an essential factor for their health. Recognition is an intermediate issue between work and pleasure, since without it there is no sense, little pleasure, or re-appropriation after alienation. Without recognition, suffering and/or defensive strategies occur ${ }^{(8)}$.

Working in the emergency room has its status within the Institution, where work organization is marked by advanced technological support in the care of patients under risk of death, and the specific knowledge of professionals on this area. Thus, it is as if the "best" professionals were practicing their activities in the "most important" place.

Still on the dimension implied in the recognition, determiners of balance and, consequently, of the work-health relation, are important in the formation of the identity of workers, since identity is always a victory on alienation at work, and in this way, there is a re-appropriation of the meaning of work $^{(8)}$.

[...] it is a very dynamic service, diverse, varied, you cannot get tired of it $[\ldots](E-3)$.

In the "variation" mentioned by the participant is where a peculiar space of the work in emergency and urgency is identified so that there can be creation in the task prescribed. Said in another way, the work predicted for these work situations can be added with creativity, inventiveness, or discovery, with a final result that comes from workers, since under risk of death not everything can be previously conceived.

This part of a person over technique also favors building an identity of nursing workers. It is stated that, in addition to the benefit in health of what is being done (saving lives), the possibility of a space for human mobilization in the task must be also considered, which is maximized by the unpredictability of situations.

[...] the emergency situation is the acute situation, you care for someone and you do not know what is happening, you do not know what were the causes, patients are not monitored, patients do not undergo intubation, you are going to do everything at that time! (E-12).

The possibility of "making everything at that time" is understood here as a space for meeting the desires and needs of workers, which means a space where subjects reestablish their balance in face of situations that could lead to pain and, thus, keep themselves healthy. Thus, dealing with the unpredictable, a demand in the emergency and urgency work, may be understood as a benefit in the organization of work to the health of nursing professionals.

Additionally, the feeling of belonging to the work process as a whole is another contributing factor in the benefit of the work in urgency and emergency for nursing health professionals. Thus, severe situations, risk of life, the intervention performed create the idea of care that is completed either by the survival or death of patients ${ }^{(5)}$.

[...] I like this kind of care, that comes and leaves, we finish the job and then we refer patients somewhere else, it is a continuous flow $[\ldots](E-3)$. 
Work in emergency and urgency has positive aspects on the health of nursing professionals. Being able to take part in the conception of work, together with the proud for its purpose and recognition that make the identity of workers, were the factors identified as definers of balance and, therefore, health at work.

\section{FINAL CONSIDERATIONS}

It is understood, therefore, that health of nursing professionals is made as of a work dynamics that is harmful at times resulting from an organizational context marked by the public health system that has many gaps, but even so, it enables workers in some ways to find original paths to meet

\section{REFERENCES}

1. Dejours C. Normalidade, trabalho e cidadania. Cadernos do CRP. 1991 outubro; 6(1):13-7.

2. Laurell AC, Noriega M. Processo de Produção e Saúde. Trabalho e Desgaste Operário. São Paulo: Hucitec; 1989.

3. Pires D. Reestruturação produtiva e trabalho em saúde no Brasil. São Paulo: Confederação Nacional dos Trabalhadores em Seguridade Social - CUT - Annablume; 1998.

4. Pitta AMF. Hospital: dor e morte como ofício. 3a ed. São Paulo: Hucitec; 1999.

5. Deslandes SF. Frágeis Deuses: profissionais de emergência entre os danos da violência e a recriação da vida. Rio de Janeiro: FIOCRUZ; 2002.

6. Dejours C. A loucura do trabalho: estudo da psicodinâmica do trabalho. São Paulo: Cortez; 1990.

7. Nunes BO. O sentido do trabalho para merendeiras e serventes em situação de readaptação nas escolas públicas do Rio de Janeiro. [dissertação]. Rio de Janeiro (RJ): Fundação Oswaldo Cruz / Escola Nacional de Saúde Pública; 2000.

8. Lancman S, Sznelwar LI, organizadores. Christophe Dejours: da psicopatologia à psicodinâmica do trabalho. Rio de Janeiro: Editora Fiocruz, Brasília: Paralelo 15; 2004.

9. Dejours C, Abdoucheli E. Itinerário Teórico em Psicopatologia do Trabalho. In: Dejours C, Abdoucheli E, Jayet C. Psicodinâmica do Trabalho: contribuições da Escola Dejouriana à análise da relação prazer, sofrimento e trabalho. São Paulo (SP): Atlas, 1994. p.119-45.

10. Stake R. Investigación com estúdios de casos. Madrid: Morata; 1998. the demands of the job and their own needs, without getting sick.

We could identify that the benefit of the work studied for the health of nursing patients lies on the symbolic value of work, given by the moral attribute of the activity. Additionally to specific knowledge to save lives, work also gives autonomy and an opportunity to create and cope with unpredictability.

Thus, to study workers' health, it is important to examine the work context, because this singularity and complexity build the relations and means that favor being health or getting sick. The relevance of considering the meaning given by human beings to their experiences is also believed, since from these experiences it is possible to understand more comprehensively physical and psychological manifestations of a collectivity.

11. Polit FD, Beck CT, Hungler BP. Fundamentos de Pesquisa em Enfermagem: métodos, avaliação e utilização. $5^{a}$ ed. Porto Alegre: Artmed; 2004

12. Bardin L. Análise de Conteúdo. Edições 70. Lisboa; 1977.

13. Costa ALRC. As múltiplas formas de violência no trabalho de enfermagem: o cotidiano de trabalho no setor de urgência e emergência clínica em um hospital público. [tese]. Ribeirão Preto (SP): Escola de Enfermagem de Ribeirão Preto/USP; 2005.

14. Elias MA, Navarro VL. A relação entre o trabalho, a saúde e as condições de vida: negatividade e positividade no trabalho das profissionais de enfermagem de um hospital escola. Rev. Latino-am Enfermagem. 2006 Ago; 14(4):517525.

15. Sato L. Trabalho e Saúde Mental. Saúde, Meio Ambiente e Condições de Trabalho - Conteúdos Básicos para uma Ação Sindical - CUT; 1996

16. Morin E. À Procura do Sentido. Carta Capital: Política, Economia e Cultura, 2003; 263(1):16-7.

17. Morin E. O Perigo da Satisfação. [entrevista]. Administração no Milênio. Rev Esc Admin UFRGS 2006 janeiro; 14(1):14-7. 